\title{
Pelatihan Public Speaking Berbasis Storytelling Sebagai Bagian Gerakan Literasi Sekolah (GLS) Di SD BPI Bandung
}

\author{
ABSTRAK \\ Yayu Sriwartini ${ }^{1,}$ Djudjur Luciana Radjagukguk ${ }^{2}$ \\ ${ }^{1}$ Universitas Nasional \\ ${ }^{2}$ Universitas Nasional \\ yayu_sriwartini@yahoo.com.dluciana_rajagukguk@yahoo.co.id
}

\begin{abstract}
Abstrak
Saat ini pemerintah melalui Kementerian Pendidikan dan Kebudayaan tengah gencar melakukan Gerakan Literasi Sekolah (GLS). Dalam mewujudkan tujuan literasi di tingkat sekolah dasar (SD), perlu ada metode sederhana dalam mendorong siswa menceritakan kembali apa yang dialaminya. Namun tidak semua siswa SD memiliki keberanian bercerita di kelas. Perasaan malu, minder, takut dan tidak percaya diri menjadi alasannya. Kondisi itu pun terjadi pada siswa/i SD BPI Bandung. Oleh karena itu diperlukan pelatihan public speaking dasar yang sederhana, dan salah satu bentuknya adalah self-storytelling. Sasaran dari kegiatan ini adalah siswa-siswi kelas V SD BPI, Jl. Halimun No. 40, Lengkong Bandung, Jawa Barat. Pada saat pelatihan siswa yang hadir berjumlah 27 orang. Adapun metode pelatihan yang digunakan adalah ceramah dan tanya jawab, praktek dengan cara bercerita serta diskusi dan diakhiri dengan validasi. Hasil kegiatan menunjukkan meski masih terdapat kekurangan, tetapi terlihat ada perubahan pada pengelolaan komunikasi verbal dan non-verbal yang diperlihatkan para siswa yang mendapat kesempatan untuk mempraktekkan penyampaian cerita pribadinya di depan kelas. Selain itu para siswa yang menjadi pendengar pun dapat mengidentifikasi nilai-nilai positif dalam kehidupan sebagai bagian dari pengetahuan baru. Kesimpulannya adalah bahwa pelatihan public speaking berbasis self-storytelling ini cukup berhasil menstimuli para siswa untuk berpikir dan berpendapat.
\end{abstract}

Kata kunci: Storytelling, Literasi, Sekolah

Key Words: Public Speaking, Gerakan Literasi, Self Storytelling 


\section{PENDAHULUAN}

Saat ini pemerintah melalui Kementerian Pendidikan dan Kebudayaan tengah gencar melakukan Gerakan Literasi Sekolah (GLS) sebagai bagian dari Gerakan Literasi Nasional (GLN). Hal ini dituangkan melalui Permendikbud nomor 23 Tahun 2015 tentang Penumbuhan Budi Pekerti, yakni setiap sekolah (SD sampai SMA) wajib menerapkan kegiatan membaca buku 15 menit sebelum memulai pelajaran. Tujuannya adalah untuk menumbuhkan minat dan keterampilan membaca di kalangan pelajar sehingga meningkatkan pengetahuannya.

Bukan tanpa alasan pemerintah memberlakukan program GLS. Dikutip dari panduan GLN Kemendikbud tahun 2017, pada tahun 2015 Survei Progamme for International Student Assessment (PISA) menunjukkan Indonesia berada di urutan ke-64 dari 72 negara. Sepanjang tahun 2012 - 2015, skor PISA untuk membaca hanya naik 1 poin dari 396 menjadi 397. Hasil tes tersebut memperlihatkan bahwa kemampuan memahami dan keterampilan menggunakan bahan-bahan bacaan, khususnya teks dokumen, pada anak-anak Indonesia usia 9 - 14 tahun berada di posisi sepuluh terbawah (Kemendikbud, 2017).

Hasil Asesmen Kompetensi Siswa Indonesia (AKSI)/Indonesia National Assessment Programme (INAP) pun sama. Kemampuan membaca, matematika, dan sains bagi anak sekolah dasar (SD) di Indonesia berada pada kategori kurang dalam kemampuan matematika sebanyak 77,13 persen dan kurang dalam membaca sebesar 46,83 persen. Artinya tingkat literasi di kalangan siswa SD masih kurang dan harus ditingkatkan (Kemendikbud, 2017).

Literasi selama ini identik dengan aktivitas membaca dan menulis, tetapi menurut Clay dan Ferguson literasi pun mencakup keterampilan berpikir menggunakan sumber-sumber pengetahuan dalam bentuk cetak, visual, digital dan auditori. Semua kemampuan tersebut dinamakan literasi informasi (www.bibliotech.us/pdfs/infoLit.pdf).

Keduanya menjabarkan bahwa komponen literasi informasi terdiri atas literasi dini, literasi dasar, literasi perpustakaan, literasi media, literasi teknologi dan literasi visual.

Pada anak-anak SD, literasi yang tepat diterapkan adalah literasi dasar (Basic Literacy), yaitu kemampuan untuk mendengarkan, berbicara, membaca, menulis dan menghitung berkaitan dengan kemampuan analisis untuk memperhitungkan, mempersepsikan informasi, mengomunikasikan, serta menggambarkan informasi berdasarkan pemahaman dan pengambilan kesimpulan. Salah satu metode yang dapat digunakan untuk mencapai tujuan gerakan literasi ini adalah storytelling, yakni penyampaian ulang apa yang dibaca oleh para siswa. Hal ini sekaligus untuk mengukur sejauhmana daya ingat siswa terhadap materi yang dibacanya.

Dalam mewujudkan tujuan literasi di tingkat sekolah dasar, storytelling merupakan metode sederhana dalam mendorong para siswa menceritakan kembali apa yang ada di dalam pikirannya. Tidak harus hal-hal yang terlalu rumit terkait dengan mata pelajaran, tetapi bisa juga tentang pengalaman pribadinya. Memulai dari penceritaan pengalaman pribadi ini akan menumbuhkan kebiasaan siswa untuk bercerita dan menyampaikan informasi lainnya.

Storytelling bisa dikatakan sebagai bagian dari kegiatan Public Speaking. Hal ini sesuai dengan definisi yang disampaikan oleh YS. Gunadi bahwa Public Speaking merupakan bentuk komunikasi lisan di depan orang banyak yang bertujuan . untuk memersuasi, mengubah opini, mengajar, mendidik, memberikan penjelasan serta informasi kepada orang tertentu (www.publicspeakingmagically.com).

Meski pada awalnya Public Speaking mengacu kepada kegiatan pidato, tetapi dalam perkembangannya Public Speaking memiliki ragam bentuk, dan salah satunya 
adalah storytelling yang merupakan bentuk sederhana dari Public Speaking.

Namun tidak semua siswa SD memiliki keberanian untuk bercerita di depan teman-temannya di kelas. Perasaan malu, minder, takut dan tidak percaya diri menjadi alasannya. Menurut Marhendi dalam surveynya ( 2016: ), siswa sekolah dasar rata-rata memiliki tingkat kecemasan dalam berkomunikasi, meski dalam kategori sedang. Tentu saja hal tersebut merupakan sebuah kewajaran terjadi pada anak-anak, termasuk pada siswa/i SD BPI Bandung, sebagai salah satu sekolah dasar inklusif. Dari hasil wawancara dengan kepala sekolah SDB BPI, Suwondo diperoleh informasi bahwa memang sebagian siswa/i masih memiliki kecemasan ketika harus berbicara di depan kelas di hadapan kawan-kawannya. Terlebih pada anak-anak berkebutuhan khusus. Suwondo mengakui bahwa ada keterbatasan dari para guru untuk secara khusus memberikan keterampilan public speaking kepada para siswanya, "Memang selama ini ada upaya guru untuk motivasi siswa agar berani mengemukakan pendapat dan berbicara di depan kelas. Tetapi itu hanya sesekali saja pada saat memberikan pelajarannya. Misalnya memanggil siswa untuk maju ke depan mengerjakan soal latihan secara bergantian. Tetapi tidak secara khusus," tuturnya.

Menurut Suwondo, keterampilan public speaking bagi para siswanya sangat diperlukan. Terlebih SD BPI merupakan salah satu SD favorit di Kota Bandung, yang selalu menyertakan siswa didiknya mengikuti ajang perlombaan. Tetapi sayangnya belum ada pembinaan secara khusus. Oleh karena itu pihaknya sangat menyambut baik kerjasama yang ditawarkan tim PKM untuk memberikan pelatihan Public Speaking berbasis storytelling. Alasannya bisa menstimulir para siswa bercerita dan mendorong siswa menyampaikan buah pemikirannya.

Mempelajari public speaking berarti tidak saja melatih keberanian untuk berbicara di depan banyak orang, tetapi juga mempelajari etika dan seni penyampaian pesan melalui bahasa verbal maupun non verbal yang disesuaikan dengan situasi, konteks dan audiens. Tentu saja public speaking tidaklah mudah. Tetapi juga tidak sulit untuk dilakukan.

Tantangan terbesar dalam public speaking adalah mengalahkan rasa takut serta ketidakpercayaan diri. Oleh karena itu belajar dan berlatih secara terus menerus akan membantu diri seseorang untuk memiliki kemampuan menguasai audiens, mengatasi rasa gugup serta berkata-kata dengan lancar. Namun demikian, seseorang ketika akan berbicara di depan umum, sebelumnya harus memiliki persiapan. Public Speaking bisa dipelajari oleh siapapun tidak terkecuali para pelajar SD salah satunya melalui metode storytelling.

Oleh karena itu dari hasil

penelusuran data melalui wawancara dengan kepala sekolah, tim PKM mempertimbangkan pentingnya memberikan pelatihan Public Speaking dasar berbasis Storytelling dengan tujuan:

1. Untuk mendorong para siswa tampil berani dan percaya diri menyampaikan pengetahuan barunya secara lisan kepada kawan-kawannya di depan kelas

2. Memotivasi anak-anak untuk tidak hanya menjadi pendengar, tetapi juga berani berbicara dan memberikan tanggapan serta pendapat mengenai apa saja yang dipaparkan oleh temannya yang sedang berbicara di depan kelas .

Menurut Frank sebagaimana dikutip Astuti, Lestari dan Yuniarni, storytelling merupakan salah satu metode yang efektif dalam mengembangkan aspek-aspek kognitif (pengetahuan), afektif (perasaan), sosial, dan aspek konatif (penghayatan) anak (2007:6). Begitu juga beberapa riset mengenai pelaksanaan storytelling di sekolah dasar ternyata bisa meningkatkan kemampuan menulis, minat membaca dan kecerdasan 
emosional siswa (Wardiah, 2017), dan meningkatkan keterampilan berbicara (Pratiwi:2016). Dengan demikian dapat diyakini bahwa storytelling merupakan salah satu metode efektif untuk menunjang program Gerakan Literasi Sekolah, khususnya di SD BPI Bandung. Agar storytelling menarik, maka para siswa perlu dibekali teknik public speaking dasar.

\section{METODE}

Pelatihan Public Speaking berbasis Strorytelling ini dilaksanakan setelah sebelumnya tim PKM melakukan observasi awal dalam rangka penjajagan dan memastikan kebutuhan yang diperlukan oleh para siswa. Dari hasil wawancara dengan kepala sekolah, diperoleh keterangan bahwa para siswa selain perlu dimotivasi untuk berani mengemukakan pendapatnya, perlu diperkenalkan pada metode lain dalam menyerap dan mengomunikasikan pengetahuannya secara lebih fleksible. Mengenalkan teknik dasar public speaking melalui metode storytelling disepakati sebagai bentuk penyampaian informasi yang dianggap santai, tidak kaku dan tidak terlalu berat, sebab siswa hanya didorong untuk menceritakan pengalaman pribadinya. Dan para siswa diminta untuk menggali nilai-nilai positif dari pengalamannya tersebut. Sasaran dari kegiatan ini adalah siswa-siswi kelas $\mathrm{V}$ SD BPI, Jl. Halimun No. 40, Lengkong Bandung, Jawa Barat. Pada saat pelatihan siswa yang hadir berjumlah 27 orang.

Kegiatan diawali dengan Pembukaan dari perwakilan sekolah sekaligus perkenalan dengan peserta, kemudian dilanjutkan dengan pemberian materi oleh Yayu Sriwartini dan Djudjur Luciana Rajagukguk secara bergantian. Pelatihan ini dilakukan di kelas VB mulai dari pukul 09.00-11.45 dengan beberapa metode berikut ini:

1) Metode ceramah dan tanya jawab.

Metode ceramah digunakan hanya pada pengantar materi tentang public speaking dan storytelling. Itu pun diselingi dengan tanya jawab yang ditujukan untuk menghidupkan suasana. Metode tanya jawab terutama digunakan untuk mengeksplorasi pengetahuan siswa tentang public speaking dan storytelling. Setelah siswa menyampaikan pengetahuan awalnya, selanjutnya tim PKM memberikan paparan dan gambaran tentang definisi serta ruang lingkup public speaking dan storytelling, termasuk memberikan contoh storytelling dan penggunaan komunikasi verbal dan non verbal ketika bercerita di depan orang banyak.

\section{2) Praktek public speaking dengan cara} bercerita

Metode berikutnya adalah praktek. Para siswa didorong untuk menceritakan pengalaman apapun yang dialaminya dalam keseharian di depan kelas. Tim PKM membiarkan para siswa bercerita dengan cara dan gaya komunikasinya masingmasing.

\section{3) Diskusi dan validasi}

Metode diskusi digunakan untuk memberi kesempatan kepada siswa yang menjadi audiens (pendengar) untuk mengidentifikasi dan menggali nilai-nilai positif apa yang terkandung di dalam pengalaman pribadi teman-temannya yang bercerita. Selain itu para siswa pun diberi kesempatan untuk memberikan tanggapan terhadap gaya komunikasi teman-temannya. Sedangkan validasi dilakukan oleh tim PKM terhadap para siswa yang melakukan storytelling. Komponen yang divalidasi terutama pada komunikasi verbal dan nonverbalnya pada saat bercerita. Pemahaman mengelola komunikasi nonverbal sangat penting ditekankan kepada siswa, karena sebagaimana dikemukan oleh Paul Ekman, bahwa komunikasi non-verbal memiliki sedikitnya lima (5) fungsi, yakni:

1. Mengurangi perilaku verbal

2. Memperteguh atau melengkapi perilaku verbal

3. Menggantikan perilaku verbal

4. Meregulasi perilaku verbal

5. Membantah perilaku verbal (Mulyana, 2007:350)

\section{HASIL dan PEMBAHASAN}

Kegiatan dilakukan sebelum masa pandemi. Di awali dengan 
perkenalan kepada para siswa kelas VB. Peserta pelatihan sebanyak 27 siswa. Tim memulai pelatihan dengan memberikan pertanyaan pemantik berikut ini "siapa yang suka grogi jika berbicara di depan orang banyak?" hampir sebagian besar siswa mengacungkan tangan. Rata-rata dari mereka merasa grogi karena malu dan tidak percaya diri kalau harus berbicara di depan kelas.

Dalam materi pengantar, tim memberikan tips untuk menghindarkan rasa grogi, takut, cemas atau pun malu. Tim pun menyampaikan materi tentang manfaat self-storytelling di antaranya (1) menambah keberanian tampil di depan umum; (2) meningkatkan kecerdasan emosional melalui keterampilan menyampaikan informasi secara lisan dan (3) mendorong siswa kreatif, karena harus berimporvisasi dengan caranya masing-masing. Selain itu di sesi pertama, yakni di 20 menit pertama tim memberikan pengetahuan terlebih dahulu tentang hal-hal penting yang harus dikuasai ketika menceritakan diri sendiri (pengalaman, keluarga, hobi dan sebagainya) di depan kelas.

Menggunakan bahasa yang disesuaikan dengan siswa-siswi SD tim PKM menyampaikan beberapa komponen yang dianggap penting public speaking, yakni komunikasi verbal dan komunikasi non-verbal, termasuk di dalamnya kontak mata, paralanguage (intonasi, volume, ritme, gelombang suara serta tempo berbicara), kinesik, postural. Selain itu ketika bercerita pun, pencerita boleh meniru-nirukan suara dan menggunakan alat peraga. Untuk mengatasi kegugupan, pencerita bisa juga memainkan gerakan tangan serta bergerak kea rah yang lan (jika berceritanya berdiri).

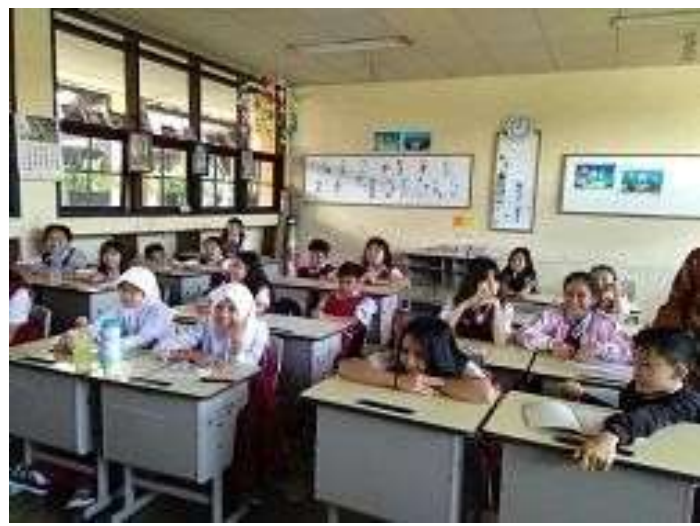

Gambar 1: Peserta sedang mendengarkan tips self-storytelling

Setelah diberikan pengetahuan mengenai teknik public speaking berbasis self-storytelling, berikutnya pada siswa diberikan kesempatan untuk mempraktekkannya di depan kelas. Tidak mudah memang untuk meminta mereka secara sukarela maju ke depan. Hanya beberapa siswa yang berani maju tampil ke depan tanpa ditunjuk. Giliran pertama adalah Abdi Raya. Dia adalah seorang penyayang binatang kucing. Kemudian dia bercerita awal mula mengapa dirinya menyukai kucing dan pengalamannya merawat kucing peliharaannya yang tertabrak. Mulai dari memeriksakannya ke dokter hewan sampai kemudian merawatnya hingga sembuh.

Dalam

menyampaikan storytellingnya, Abdi Raya belum terlalu banyak memainkan komunikasi nonverbal. Kontak matanya hanya terbatas pada temantemannya yang persis berada di depan matanya saja. Dia juga lebih sering memainkan kakinya untuk menghilangkan kegugupan. Namun nada suaranya sudah cukup keras dan sesekali memeragakan bunyi suara kucing, sebab dia tidak hanya bercerita dengan kalimat tidak langsung, namun juga terkadang diselingi dengan kalimat-kalimat atau ucapan-ucapan langsung. Salah satunya ketika dia menyuarakan suara kucing. Justru hal itu cukup menghidupkan suasana, sebab memantik teman-temannya tertawa dan turut menirukan. 
Kontak mata Abdi yang terbatas dapat dipahami karena ketakutan atau kegugupan, sehingga Abdi mencari aman dengan mengarahkan kontak pada hanya pada teman-teman yang ada di depanya saja. Padahal yang terbaik adalah pembicara melihat atau "menyapu" seluruh temannya dengan pandangan matanya. Menurut Olii setidaknya ada dua hal fungsinya. Pertama, menunjukkan kesan interaktif dan menghargai pendengarnya. Kedua, kontak mata bisa "menahan" pendengar untuk tetap konsentrasi mendengarkan apa yang disampaikan. Bahkan perlu sesekali pembicara menajamkan pandangan matanya pada orang tertentu secara bergantian. Cara seperti ini bisa dijadikan upaya untuk pribadi yang hangat (2007:64)

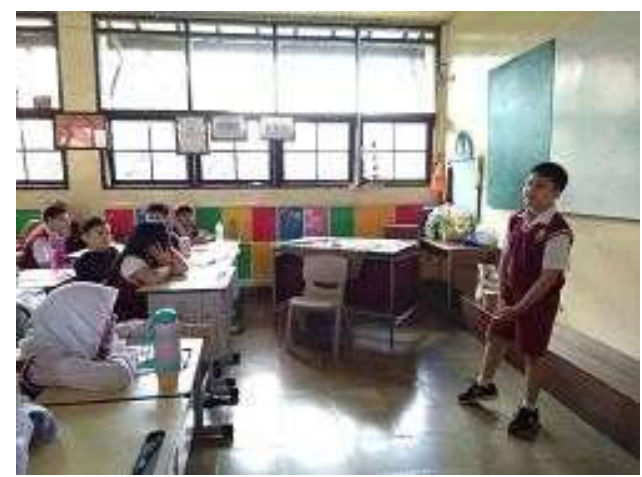

Gambar 2: Penampilan Self Story Telling Abdi Raya

Dari cerita yang disampaikan Abdi, para siswa mengidentifikasi beberapa nilai positif, di antara cinta kasih dankepedulian kepada mahluk lain cipataan Tuhan. Pesan yang disampaikan Abdi dalam ceritanya adalah hendaknya setiap insan manusia memiliki empati kepada binatang, dan merawatnya dengan baik ketika binatang tersebit dipelihara, jangan mengianyiakannya.

Siswa berikutnya adalah Helena. Helena bercerita tentang kedekatan dia dengan kakak dan adiknya. Selalu kompak dengan saudara kandungnya, dan bahkan beberapa kostum di rumahnya sama. Helena merupakan anak kedua dan memiliki hobi menggambar sejak dari TK dan dia sering mengikuti perlombaan, mulai dari lomba mewarnai sampai lomba menggambar. Menurutnya dia sudah berkali-kali memenangi kompetisi lomba menggambar. Pelajaran yang dapat dipetik para siswa dari cerita Helena adalah pentingnya membangun kebersamaan dengan saudara kandung.

Pengalaman pribadi Helena menunjukkan betapa bermanfaatnya ketika dapat menjaga hubungan yang baik dengan kakak atau adik. Kekompakan yang terlihat pada Helena dan suadara-saudaranya memberi pelajaran yang positif bagi siswa lainnya agar menghindari pertengkaran dan persaingan dengan suadara kandung. Nilai lainnya yang tersirat dari cerita Helena adalah pentingnya mencipatakan kerukuanan, sebab dengan rukun akan memudahkan manusia untuk saling memberi, mengasihi dan menolong. Jika dilihat dari cara komunikasinya, kemampuan Helena bercerita cukup baik. Suaranya lantang dan tidak malu-malu. Secara interaksi, dia mampu menggunakan komunikasi mata. Pandangan matanya tidak hanya tertuju pada satu baris di depan matanya saja, tapi dia mampu "menyapu" kawan kawannya yang duduk di barisan lainnya. Hanya saja belum bisa mengelola gerakan tangan. Untuk menghilangkan rasa groginya, dia lebih sering menyilangkan tangan di belakang, sehingga komunikasi non-verbalnya tersebut sedikit mengganggu penampilannya. Menurut Buckley (2008:181), gerakan tangan dengan intensitas tertentu menunjukkan emosi seseorang seperti resah, gelisah, gugup atau perasaan emosional lainnya. Oleh karena itu harus dikontrol.

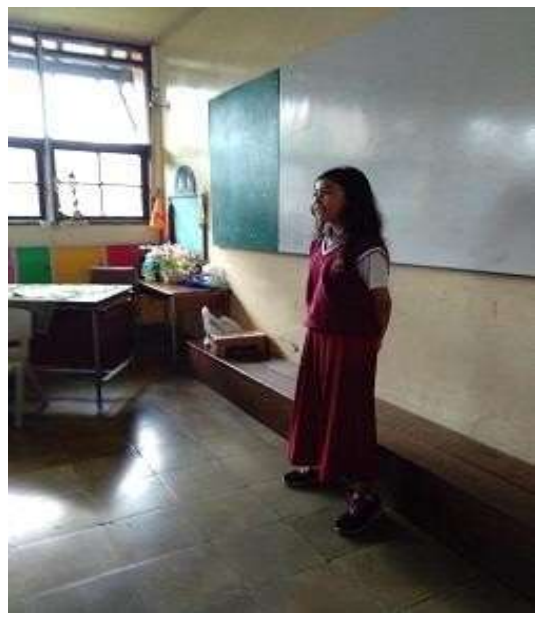

Gambar 3: Penampilan Self Story Telling Helena 
Berikutnya penampilan ketiga adalah Jelita Delia. Jelita aktif mengikuti kursus Bahasa Inggris, dan bahkan sudah beberapa kali mengikuti kompetisi Bahasa Inggris di tempat kursusnya. Karena itu tidak heran, dia memilih berbeda dengan dua kawan sebelumnya, Jelita memilih bercerita dengan Bahasa Inggris. Tema self storytelling-ya adalah Holiday in Bali. Dia menceritakan pengalamannya berlibur dengan keluarga ke Bali.

Jelita dan keluarga lebih banyak mengunjungi tempat-tempat yang menunjukkan kearifan lokalnya, seperti ke pesawahan terasering, lalu ke desa wisata penglipuran yang dikenal dengan kebersihan dan kerapihan tempatnya. Menurut Jelita kondisi tersbut tidak lepas dari kedisiplinan, ketertiban dan kekuatan gotong royong warganya dalam menjaga lingkungan agar bersih dan nyaman. Nilai-nilai itulah yang bisa ditiru dan diimplementasikan dalam kehidupan kita.

Secara komunikasi, dia cukup fasih menceritakan pengalaman berliburnya dengan Bahasa Inggris. Kepercayaan dirinya cukup tinggi di bandingkan kedua kawannya. Paralanguagenya cukup bagus, yakni suaranya lantang, pelafalannya jelas, volume, intonasi, nada serta pemilihan diksi pun tepat. Begitu pula dengan kinesik (komunikasi yang disampaikan melalui mimik muka). Jelita berhail mengelola mimik muka yang menunjukkan semangat. Tetapi sayangnya dia memilih postur yang tegap dari awal sampai selesai. Hal ini memperlihatkan sedikit kurang relax dan kaku. Menurut Carnegie dan Esenwein bahasa tubuh yang baik dapat terlihat dari keluwesan dalam memainkan postur tubuh (2013:201).

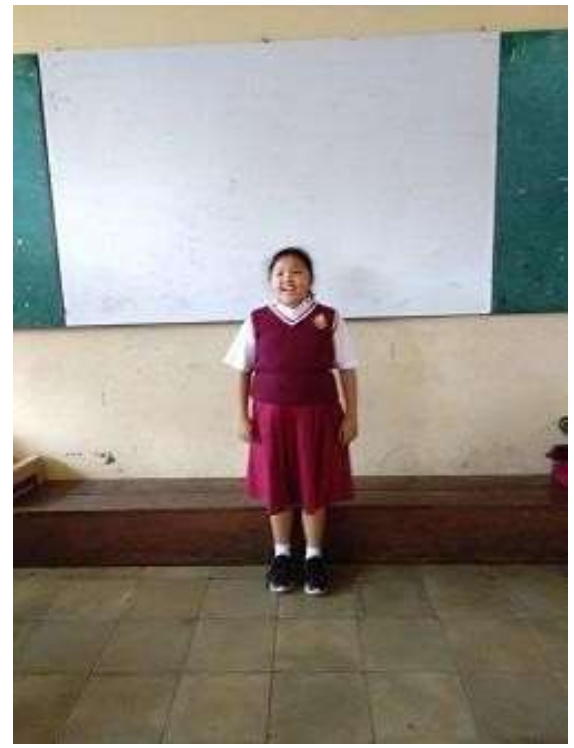

Gambar 4: Penampilan Self -Storytelling Jelita

Siswa terakhir yang berani maju ke depan adalah Aidil. Aidil termasuk yang dapat mencairkan suasana, sebab gaya berceritanya yang diselingi dengan sedikit humor, seperti misalnya ketika slip tangue, dia spontan mengatakan "Eh salah, bukan itu deng”. Celetukannya merupakan bagian dari dia menghilangkan rasa gugup. Self storytelling Aidil mengenai kebiasaan dia menghabiskan sore harinya dengan bermain sepeda bersama temantemannya di lingkungan rumah.

Menurut para siswa lainnya ada beberapa pelajaran positif yang bisa dipetik dari pengalaman Aidil di antaranya menjaga interaksi sosial dan kerukunan dengan kawan, menggiatkan olahraga sehingga menyehatkan tubuh dan pikiran serta menghilangkan jenuh.

Secara verbal, cara bercerita terlihat relax. Aidil cukup mampu menguasai diri ketika ada kesalahan, dengan cara terdiam sejenak, memiringkan kepalanya sambil sedikit mengernyitkan kening, lalu berikutnya dia akan meralat apa yang dia ceritakan. Dari bahasa non verbal dia sering tersenyum ketika ada kesalahan. 


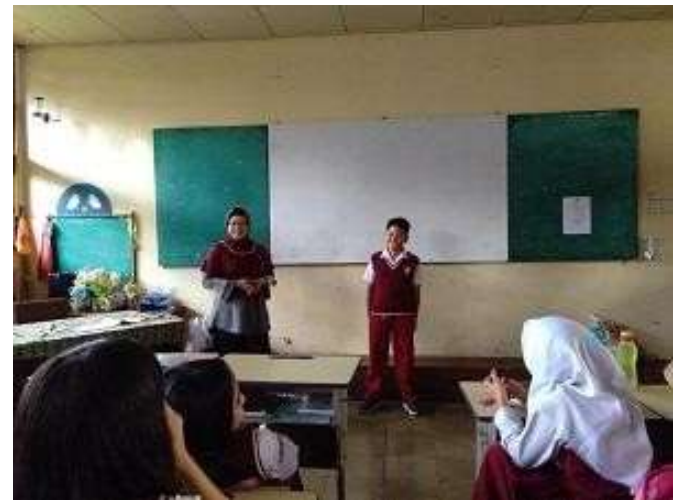

Gambar 5: Penampilan Self Story Telling Aidil

\section{KESIMPULAN}

Jika melihat penampilan public speaking keempat siswa melalui self storytelling-nya, sebenarnya masih banyak yang perlu dibenahi. Namun keberanian mereka perlu diapresiasi. Secara verbal keempatnya cukup mampu berbicara dengan suara yang keras dan lantang, tidak tersendat-sendat. Hal ini penting dalam public speaking Secara postural, meski keempatnya masih terlihat belum luwes dan hanya terpaku di satu titik tempat saja, namun mereka cukup mampu memperlihatkan tampilan diri yang tegak. Komunikasi mata pun sudah terlihat dari beberapa, meski semuanya mampu berkomunikasi dengan teman-temannya melalui mata. Gerakan tangan tidak terlalu banyak dimainkan. Padahal menggerakkan tangan bisa menjadi alternatif untuk mendukung improvisasi penceritaan. Namun demikian jika dikaitkan dengan program Gerakan Literasi Sekolah yang bertujuan mendorong para siswa aktif memperoleh tambahan ilmu pengetahuan, self-storytelling ini cukup berhasil menstimuli para siswa untuk menggali nilainilai kehidupan yang positf yang terkandung dalam cerita temannya. Hal ini menunjukkan keefektifan teknik selfstorytelling mendorong siswa untuk berpikir dan berpendapat.

\section{UCAPAN TERIMA KASIH}

Kegiatan pelatihan public speaking berbasis self-storytelling di SD BPI Bandung ini tidak akan terlaksana jika tidak ada bantuan dan kerjasama dari berbagai pihak. Oleh karena itu tim mengucapkan terima kasih kepada (1) Universitas Nasional yang telah memberikan bantuan dana; (2) Kepala Sekolah SD BPI Bandung yang telah memfasilitasi kegiatan sehingga terselenggara dengan baik; (3) Guru di kelas VB yang telah bekerjasama mempersilahkan jam pelajarannya untuk diisi oleh kegiatan pelatihan serta (4) para siswa yang dengan tertib dan antusias mengikuti pelatihan dan mempraktekkannya di dalam kelas.

\section{DAFTAR PUSTAKA}

Asfandiyar, Andi Yudha. 2007. Cara Pintar Mendongeng. Jakarta: Mizan

Buckley, Susan G. 2008. Buku Pintar Bahasa Tubuh. Jakarta: Cerdas Pustaka Publisher

Carnegie, Dale \& Esenwein, J. Berg. 2013. Buku Sakti Pucblic Speaking. Jakarta: Visi Media

http://www.bibliotech.us/pdfs/infoLit.p $\underline{\text { df }}$

https://www.publicspeakingmagically.com/pe ngertian-public-speaking.html

Marhendi. 2016. Survey Tentang Kecemasan Komunikasi Siswa Sekolah Dasar. Jurnal Pendidikan Sosial. Sains dan Humaniora, vol 2 no. 1 tahun 2016. http://ejournal.uinsuska.ac.id/index.php/suaraguru/ar ticle/view/2035

Mulyana, Dedi. 2007. Ilmu Komunikasi: Suatu Pengantar. Bandung: PT. Remaja Rosdakarya. 
Olii, Helena. 2007. Public Speaking. Jakarta:

PT. Indeks

Panduan Gerakan Literasi Nasional Kementerian Pendidikan dan Kebudayaan. 2017

Pratiwi, Rosalina Rizki. 2016. Penerapan Metode Storytelling Untuk Meningkatkan Keterampilan Berbicara Siswa Kelas Ii Sdn S4 Bandung. Jurnal Pendidikan Guru Sekolah Dasar, Vol. 1 No. 1, Desember 2016, hlm. 199-207. https://ejournal.upi.edu/index.php/jpg sd/article/view/9074

Roswita Oktavianti, Farid Rusdi. Belajar Public Speaking Sebagai komunikasi yang Efektif

https://journal.untar.ac.id/index.php/b aktimas/article/view/4335

Wardiah, dessy. 2017. Peran Storytelling Dalam Meningkatkan Kemampuan Menulis, Minat Membaca Dan Kecerdasan Emosional Siswa. Jurna; Wahana Didaktika Vol. 15 No.2 Mei 2017 : 42-56. https://jurnal.univpgripalembang.ac.id/index.php/didaktika /article/view/1236

Yuliati,Nova. Roxhim, Muhammad. Lilis, Dede. 2014. Pelatihan Keteramipan Dasar Public Speaking Bagi Siswa Sma Di Kota Bandung. http://prosiding.lppm.unisba.ac.id/in dex.php/sosial/article/viewFile/158/ $\underline{96}$ 